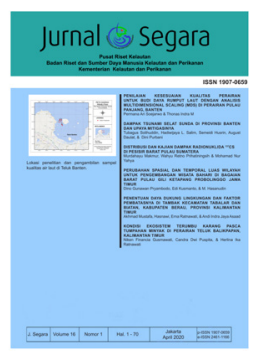

JURNAL SEGARA

http://ejournal-balitbang.kkp.go.id/index.php/segara

ISSN : 1907-0659

e-ISSN : 2461-1166

Nomor Akreditasi: 766/AU3/P2MI-LIPI/10/2016

\title{
PERUBAHAN SPASIAL DAN TEMPORAL LUAS WILAYAH UNTUK PENGEMBANGAN WISATA BAHARI DI BAGAIAN BARAT PULAU GILI KETAPANG PROBOLINGGO JAWA TIMUR
}

\section{SPATIAL CHANGE AND TEMPORAL LANDMASS AREA FOR THE DEVELOPMENT OF A MARINE TOURISM IN THE WEST PART OF GILI KETAPANG PROBOLINGGO, EAST JAVA}

\author{
Dino Gunawan Pryambodo'), Edi Kusmanto'), M. Hasanudin²), \& Nasir Sudirman"1) \\ 1)Pusat Riset Kelautan \\ Badan Riset dan Sumber Daya Manusia Kelautan dan Perikanan \\ KKPJI. Pasir putih 1, Ancol Timur Jakarta 14430, \\ 2)Pusat Penelitian Oseanografi - LIPI
}

Diterima: 28 Januari 2020; Diterima Setelah Perbaikan: 22 April 2020; Disetujui Terbit: 25 April 2020

\begin{abstract}
ABSTRAK
Pulau Gili Ketapang yang berpenduduk padat, dengan kepadatan mencapai 12.356 jiwa/ km² dan mempunyai luasan sebesar 68 hektar atau 0,68 km² termasuk katagori pulau kecil. Adanya Perda Kab. Probolinggo No15 Tahun 2001 menjadikan Pulau Gili Ketapang menjadi salah satu destinasi wisata bahari di Kab.Probolinggo. Pesona pasir putih di bagian barat wilayah Pulau Gili Ketapang menjadikan salah satu daya tarik bagi wisatawan. Perubahan luasan wilayah hamparan pasir putih tersebut berkurang dan sudah pasti akan berdampak terhadap keragaman destinasi wisata. Data dari google earth image digunakan sebagai sumber masukan utama untuk membuat peta perubahan wilayah selain penelitian lapangan (seperti pengukuran garis pantai, batimetri dan arus) di wilayah perairan Gili Ketapang. Hasil analisis data citra Satelit dari tahun 2004 sampai tahun 2018 ditemukan adanya penyusutan luas wilayah untuk pasir putih di bagian barat Pulau Gili Ketapang sebesar 0,288 Ha. Batimetri Perairan Gili Ketapang secara umum memiliki kedalaman terukur antara 0-34 m, Daerah terdalam terdapat disebelah utara Pulau Gili Ketapang dengan jarak sekitar 1.700 m. Sebelah Barat dari Pulau Gili Ketapang memiliki dasar laut yang dangkal kurang dari $20 \mathrm{~m}$ sehingga sangat cocok untuk dikembangkan menjadi daerah wisata bahari.
\end{abstract}

Kata Kunci : Pulau Gili Ketapang, Wisata Bahari, Citra Satelit, Batimetri.

\section{ABSTRACT}

Gili Ketapang Island is densely populated, with a density reaching 12,356 inhabitants / $\mathrm{km}^{2}$ and has an area of 68 hectares or $0.68 \mathrm{~km}^{2}$ including the small island category. District Regulation Probolinggo No. 15 Year 2001 makes Gili Ketapang Island one of the marine tourism destinations in Probolinggo Regency. The charm of white sand in the western part of the Gili Ketapang Island region makes it one of the attractions for tourists. Changes in the extent of the white sand area are reduced and will certainly have an impact on the diversity of tourist destinations. Data from google earth image is used as the main input source for making maps of regional changes in addition to field research (such as measurement of coastline, bathymetry and currents) in the Gili Ketapang waters. The results of the analysis of satellite imagery data from 2004 to 2018 found an area shrinkage for white sand in the western part of Gili Ketapang Island by $0.288 \mathrm{Ha}$. Bathymetry The waters of Gili Ketapang generally have a measured depth between 0-34 $\mathrm{m}$, the deepest area is on the north side of Gili Ketapang Island with a distance of about $1700 \mathrm{~m}$. The west side of Gili Ketapang Island has a shallow sea floor of less than $20 \mathrm{~m}$ so it is suitable to be developed into a marine tourism area.

Keywords: Gili Ketapang Island, Marine Tourism, Satellite Imagery, Bathymetry.

Corresponding author:

JI. Pasir Putih I Ancol Timur, Jakarta Utara 14430. Email: dinogunawan77@gmail.com 


\section{PENDAHULUAN}

Pulau Gili Ketapang merupakan pulau kecil terletak di sebelah utara wilayah Kabupaten Probolinggo yang mempunyai luas 68 hektar dengan jarak kurang lebih 12,1 Km dari kota probolinggo (BPS Kabupaten Probolinggo, 2017). Pulau Gili Ketapang termasuk dalam kategori Pulau Kecil menurut Peraturan Menteri Perikanan dan Kelautan No. 41 Tahun 2000. Pulau ini dikelilingi oleh pasir putih dengan air laut yang jernih, sehingga tampak berwarna biru, di bagian selatan dan barat pulau pantainya berpasir putih dan sisi bagian timur dan utara pulau berupa pantai batu karang.

Luas wilayah bagian barat Pulau Gili Ketapang selalu mengalami perubahan karena adanya hamparan pasir putih. Hamparan pasir putih tersebut selalu mengalami perubahan bentuk maupun luasnya di karenakan oleh pengaruh gelombang laut (Hidayati et al., 2016). Penentuan luas suatu wilayah dapat dibantu dengan memetakan bumi dari superimposisi gambar yang dikumpulkan dari pemetaan satelit, fotografi udara dan globe GIS (Thankachan et al., 2013). Data citra penginderaan jauh merupakan gambaran permukaan bumi, dapat memberikan informasi secara spasial dengan resolusi yang baik sehingga bermanfaat untuk memantau perkembangan wilayah.

Salah satu citra satelit yang memiliki resolusi spasial yang memadai adalah citra Satelit Astrium. Citra tersebut dikompilasi oleh Google Earth dan ditampilkan sebagai Google earth image. Google earth merupakan sebuah program globe virtual yang sebenarnya disebut Earth Viewer dan dibuat oleh Keyhole, Inc. Google Earth memiliki data model elevasi digital (DEM) yang dikumpulkan oleh Misi Topografi Radar Ulang Alik NASA. Google Earth mendukung pengelolaan data Geospasial tiga dimensi melalui Keyhole Markup Language (KML). Selain itu, Google Earth mempermudah pengguna mencari alamat (untuk beberapa negara), memasukkan koordinat atau menggunakan mouse untuk mencari lokasi (Thankachan et al., 2013).

Usaha penyediaan data dan informasi mutakhir serta sistem pengelolaannya menggunakan interpretasi google earth merupakan alternatif pemecahan masalah yang baik dalam menyediakan data untuk pemetaan wilayah. Selain beresolusi tinggi juga selalu diperbaharui sehingga dapat digunakan untuk mendapatkan informasi tentang perubahan permukaan bumi secara terus menerus dan dalam skala kecil sekalipun. Selain itu dibutuhkan informasi yang lengkap untuk menentukan proses dan pola perubahan wilayah, sehingga diperlukan sumber informasi tambahan menggunakan teknik penelitian lapangan. Penelitian lapangan dimaksudkan untuk melengkapi informasi sehingga dapat membedakan perubahan wilayah yang tergambar pada google earth (Hardianti \& Santoso, 2008). Untuk itu google earth image digunakan sebagai sumber masukan utama untuk membuat peta perubahan wilayah selain penelitian lapangan yang berupa pengukuran garis pantai, batimetri dan pola arus di wilayah perairan Gili Ketapang.

Perubahan luasan wilayah terutama di bagian barat Pulau Gili Ketapang yang berupa hamparan pasir putih dan merupakan salah satu daya tarik para wisatawan. Luasan wilayah hamparan pasir sangat berkaitan dengan potensi wisata bahari (Perda Kab. Probolinggo No.16 Tahun 2005) karena kehilangan hamparan pasir tersebut akan mengurangi keragaman destinasi wisata sehingga penelitian tentang penentuan luas wiayah tersebut menjadi penting. Untuk itu tujuan dari penelitian ini adalah memetakan luas wilayah hamparan pasir di bagian barat pulau Gili Ketapang untuk mendukung kegiatan wisata bahari.

\section{METODE PENELITIAN}

Penelitian dilakukan pada 29 Juni hingga 7 Juli 2018 di perairan Gili Ketapang, Kabupaten Probolinggo Provinsi Jawa Timur (Gambar 1), meliputi pengukuran luas wilayah, batimetri dan kecepatan serta arah arus.

Pengukuran luas wilayah secara langsung menggunakan GPS Garmin 276C mengelilingi Pulau Gili Ketapang dengan interval perekaman setiap 3 detik. Luas wilayah berdasarkan penginderaan jauh menggunakan citra satelit yang tersedia pada google earth dari https://www.google.com/int//id/earth/. Data yang ditampilkan sebagai Google earth image merupakan data luasan wilayah dari citra satelit astrium yang dikompilasi oleh Google Earth dan sejak 2004 hingga 2018. Google earth image dipilih dengan selang waktu lima tahunan, 2004, 2009, 2014, dan 2018, sedangkan untuk 2018 terdapat 3 citra yang direkam pada April, Agustus dan November 2018.

Pengukuran arus dan batimetri menggunakan ADCP (Acoustic Doppler Current Profiler) tipe 1200 $\mathrm{KHz}$ yang ditambatkan di sisi perahu nelayan yang cukup stabil dan memadai dengan sensor transduser menghadap ke bawah (downward-looking). ADCP dipasang pada kerangka aluminium sedemikian rupa sehingga sensornya terletak di dalam air dan posisinya tidak berubah sewaktu kapal bergerak (Gambar 2). Pengoperasian ADCP dapat dilakukan sambil perahu berjalan dengan kecepatan 6 knot dengan GPS Garmin $276 \mathrm{C}$ untuk penentuan posisi spasial lokasi penelitian. Pengoperasian ADCP selalu dibarengi dengan program komputer yang mengontrol perekaman dan pengolahan data serta dihubungkan dengan GPS yang memberikan posisi pada setiap data arus dan data 


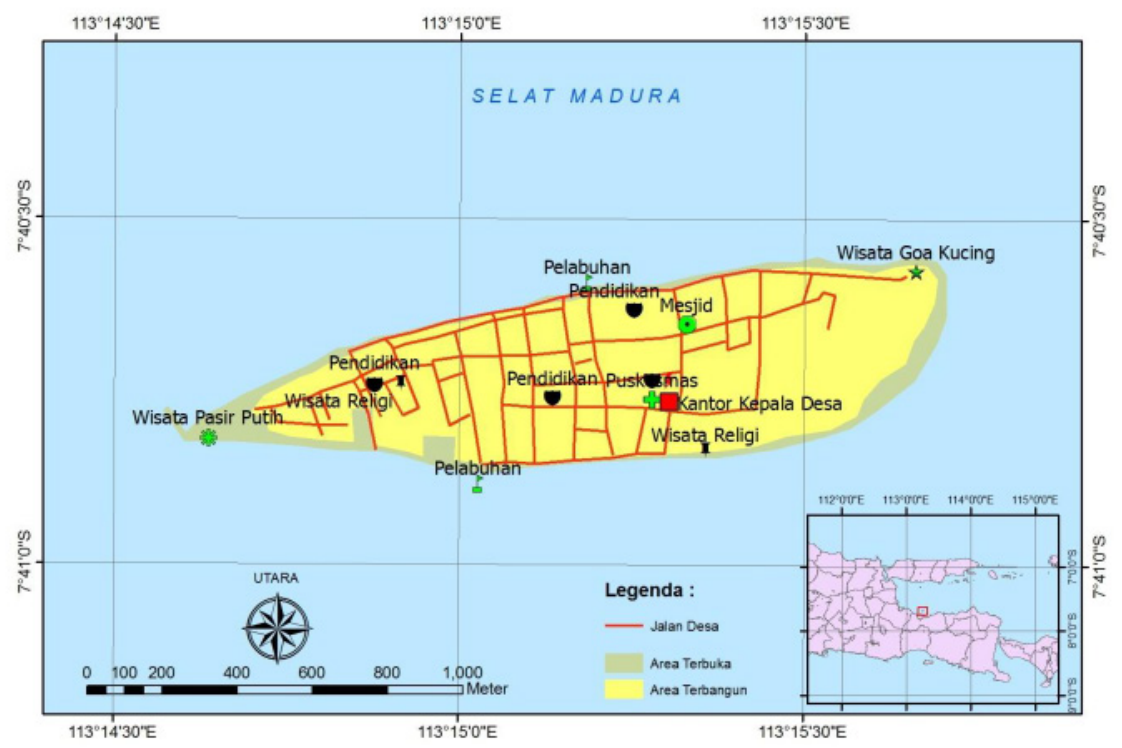

Gambar 1. Lokasi penelitian.

batimetri (Kusmanto, 1996). Data kecepatan dan arah arus dari ADCP $1200 \mathrm{KHz}$ diperoleh dari setiap lapisan kedalaman air (bin) mulai dari $1 \mathrm{~m}$ dari permukaan hingga $21 \mathrm{~m}$ dengan interval kedalaman setiap 0,5m dan ditampilkan dalam bentuk sebaran spasial.

Data batimetri ditampilkan dalam bentuk kontur kedalaman dan kontur 3 dimensi untuk melihat bentuk topografi dasar laut. Pemetaan Kontur dan Pemodelan Spasial 3 Dimensi ini berbasiskan pada software Surfer. Surfer adalah salah satu perangkat lunak yang digunakan untuk pembuatan peta kontur dan pemodelan tiga dimensi dengan mendasarkan pada grid (Budiyanto, 2005). Data tersebut diolah menggunakan Surfer 11 dengan metode Kriging yaitu interpolasi geostatistik atau sebagai penghalus, yang mampu menghubungkan titik-titik ekstrim tanpa mengisolasinya (Siregar \& Selamat, 2009).

\section{HASIL DAN PEMBAHASAN}

\section{Perkembangan hamparan Pasir}

Berdasarkan data citra satelit astrium yang dikompilasi oleh Google Earth dan ditampilkan sebagai Google earth image, Pulau Gili Ketapang selalu mengalami perubahan luas secara dinamis, tertutama pada sisi bagaian barat yang berupa hamparan pasir. Terlihat bahwa terdapat perbedaan luasan yang signifikan antara 2004, 2009, 2014, dan 2018. Pada 2004, hamparan pasir relatif lurus ke arah barat, lima tahun kemudian,2009 mengalami perubahan dan membelok ke arah barat laut dan kemudian pada 2014 mirip dengan citra satelit 2004 (Gambar 3).

Hasil penginderaan jauh Google earth image selama periode tahun 2018 terlihat adanya fenomena yang berbeda. Pada 13 April mempunyai kemiripan dengan 16 Agustus yang menunjukkan hamparan

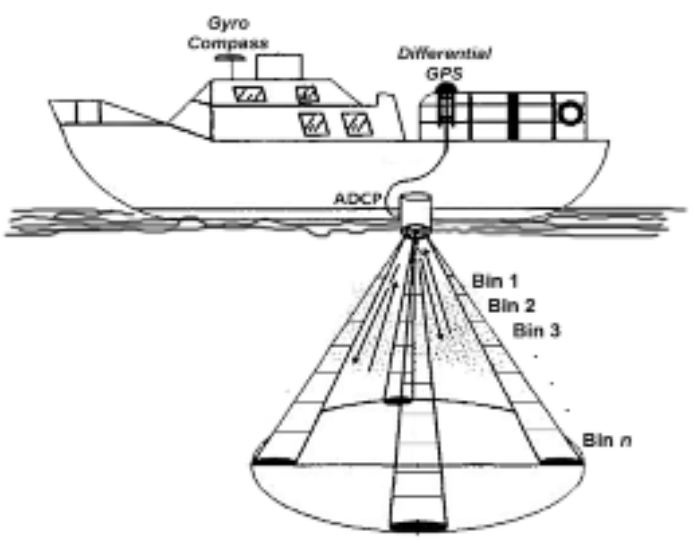

Gambar 2. Metode pengambilan data pada ADCP secara downward-looking pada ADCP bergerak (Dwinovantyo, 2017). 

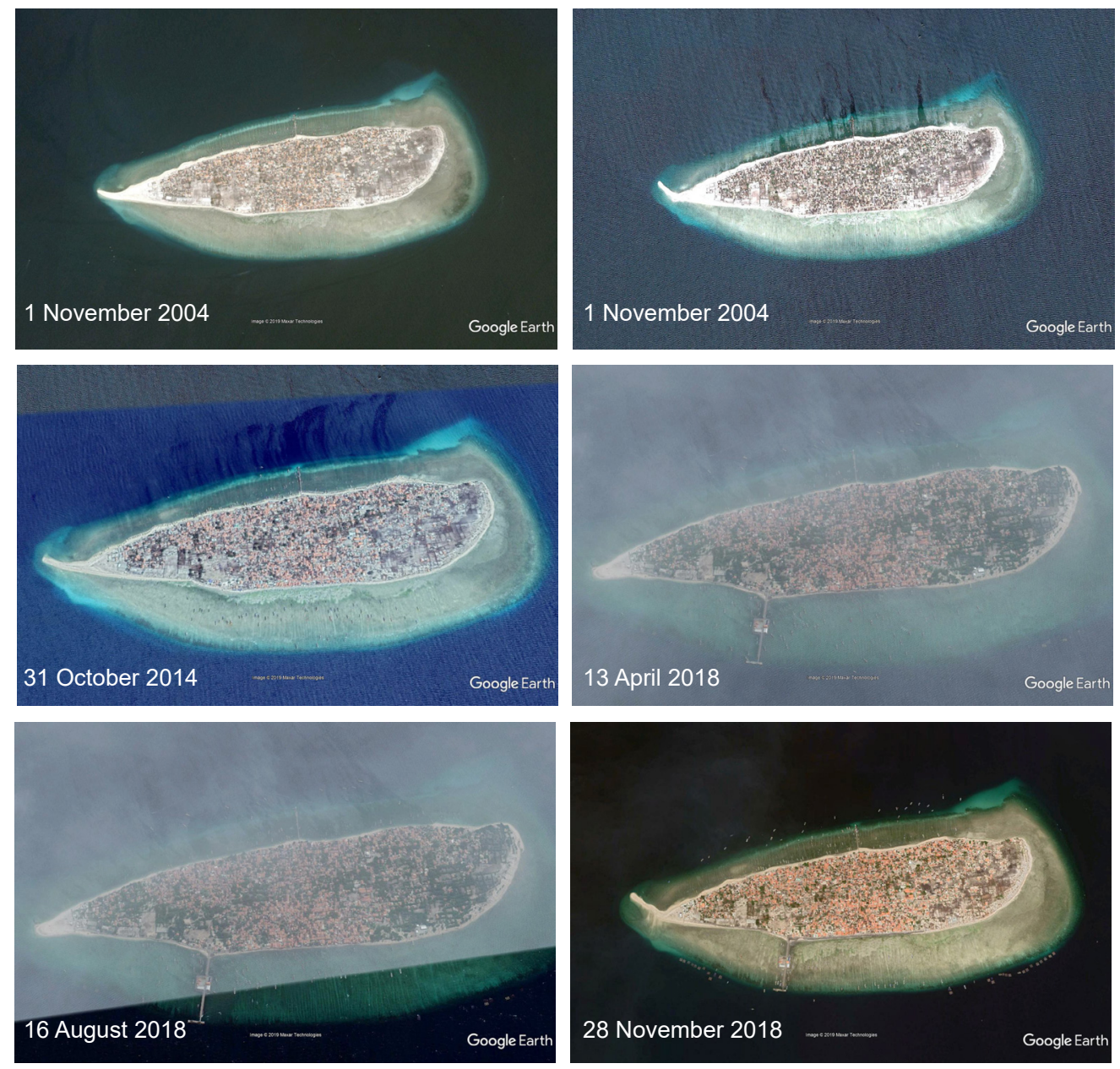

Gambar 3. Citra Satelit Astrium yang dikompilasi oleh Google Earth dan ditampilkan sebagai Google earth image, Pulau Gili ketapang secara menerus lima tahunan.

pasir tersebut relatif kecil dan menyatu dengan daratan utama sedangkan pada November 2018 hamparan pasir kembali menjulur ke arah barat laut. Fenomena tersebut menunjukkan adanya pengaruh luar yang kuat yang mampu megubah bentuk hamparan pasir di bagian barat pulau Gili Ketapang.

\section{Garis pantai dan Perbandingan Luas Wilayah}

Dalam kurun waktu kurang lebih 14 tahun, pantai di bagian barat Pulau Gili Ketapang mengalami pergeseran sebagaimana terlihat dari tumpang susun (overlay) garis pantai terkoreksi hasil pengukuran
Agustus 2018 dengan citra satelit Google earth image 2004, 2009, 2013 dan 2018 yang digambarkan dengan garis warna abu abu untuk pengukuran dengan GPS, warna coklat, hitam, hijau, biru, ungu dan merah masing masing untuk untuk Google earth image 2004, 2009, 2013 dan 2018 (bulan April, Agustus dan November) (Gambar 4).

Perbandingan luas yang dihitung dari titik $113,244^{\circ} \mathrm{E}$ di bagian timur hamparan pasir seperti yang ditunjukkan dalam Tabel 1 dan pada Gambar 4. Berdasarkan peta hamparan pasir yang

Tabel 1.

Luas wilayah hamparan pasir di bagian barat Pulau Gili Ketapang yang dihitung dari bujur $113,244^{\circ} \mathrm{E}$.

\begin{tabular}{llllll}
\hline No & Tahun & Bulan & Luas (derajat) & Luas $\left(\mathbf{m}^{2}\right)$ & Luas $(\mathrm{Ha})$ \\
\hline 1 & 2004 & Citra, November & $9,462 \mathrm{E}-07$ & $11.683,35$ & 1,168335 \\
2 & 2009 & Citra, September & $9,127 \mathrm{E}-07$ & $11.269,7$ & 1,12697 \\
3 & 2014 & Citra, Oktober & $6,402 \mathrm{E}-07$ & $7.904,968$ & 0,790497 \\
4 & 2018 & Citra, April & $2,084 \mathrm{E}-07$ & $2.573,251$ & 0,257325 \\
5 & 2018 & Citra, Agustus & $2,135 \mathrm{E}-07$ & $2.636,224$ & 0,263622 \\
6 & 2018 & Cita, November & $7,127 \mathrm{E}-07$ & $8.800,173$ & 0,880017 \\
7 & 2018 & GPS, Juli & 2,274E-07 & $2.807,857$ & 0,280786 \\
\hline
\end{tabular}




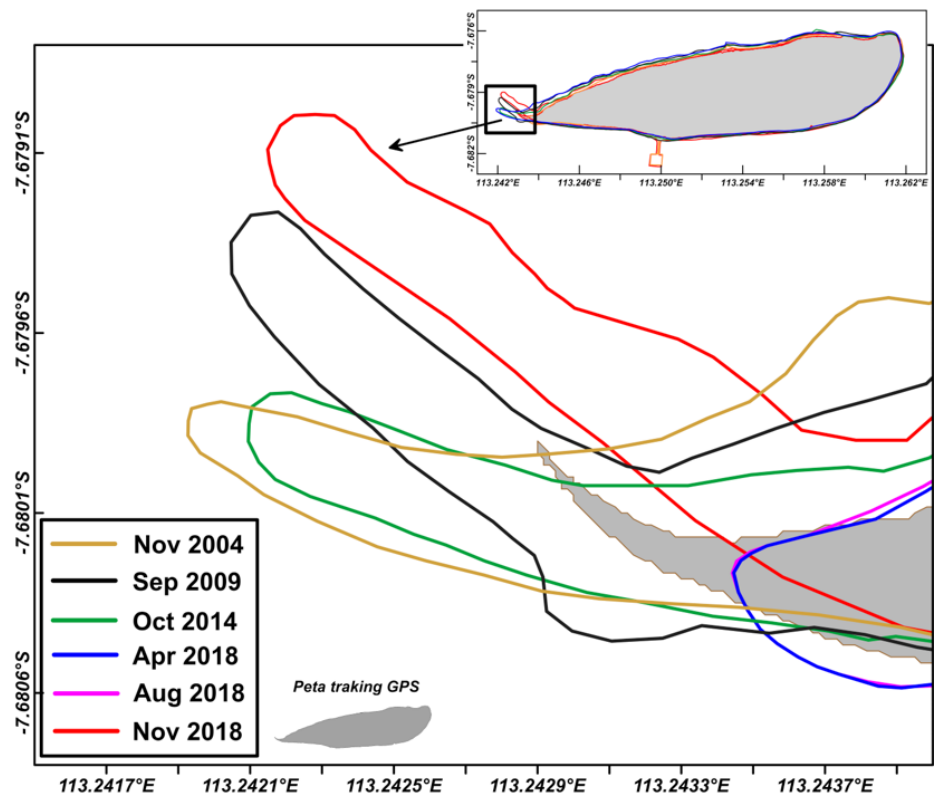

Gambar 4. Peta hamparan pasir yang ditumpangtindihkan mulai dari tahun 2004 hingga 2018 dengan hasil pengukuran dengan GPS yang dilakukan pada bulan Juli 2018.

ditumpangtindihkan mulai dari 2004 hingga 2018 dan hasil pengukuran yang dilakukan pada Juli 2018 terjadi adanya perbedan yang signifikan. Hasil pengukuran pada Juli sekitar 0,281 $\mathrm{Ha}$ sedangkan citra satelit yang paling dekat dengan pengukuran adalah bulan Agustus 2018 selkitar 0,262 $\mathrm{Ha}$, terdapat perbedaan luas $0,019 \mathrm{Ha}$. Secara umum, perbedaan luas yang signifikan selama kurun waktu 14 tahun, yaitu antara citra 2004 dengan citra 2018 menyusut sekitar 0,288 $\mathrm{Ha}$.

\section{Batimetri}

Batimetri merupakan ukuran tinggi rendahnya dasar laut (kedalaman laut), sehingga peta batimetri memberikan informasi tentang dasar laut, di mana informasi tersebut dapat memberikan manfaat pada beberapa bidang yang berkaitan dengan dasar laut (Try, 2015). Perkembangan teknologi saat ini untuk pemetaan batimetri bisa dilakukan dengan teknologi akustik yaitu menggunakan gelombang suara sehingga penggunaan teknologi ini lebih baik karena tidak merusak lingkungan di sekitar lokasi penelitian (Ridho, 2017).

Batimetri Perairan Gili Ketapang secara umum memiliki kedalaman terukur antara 0-34m daerah yang

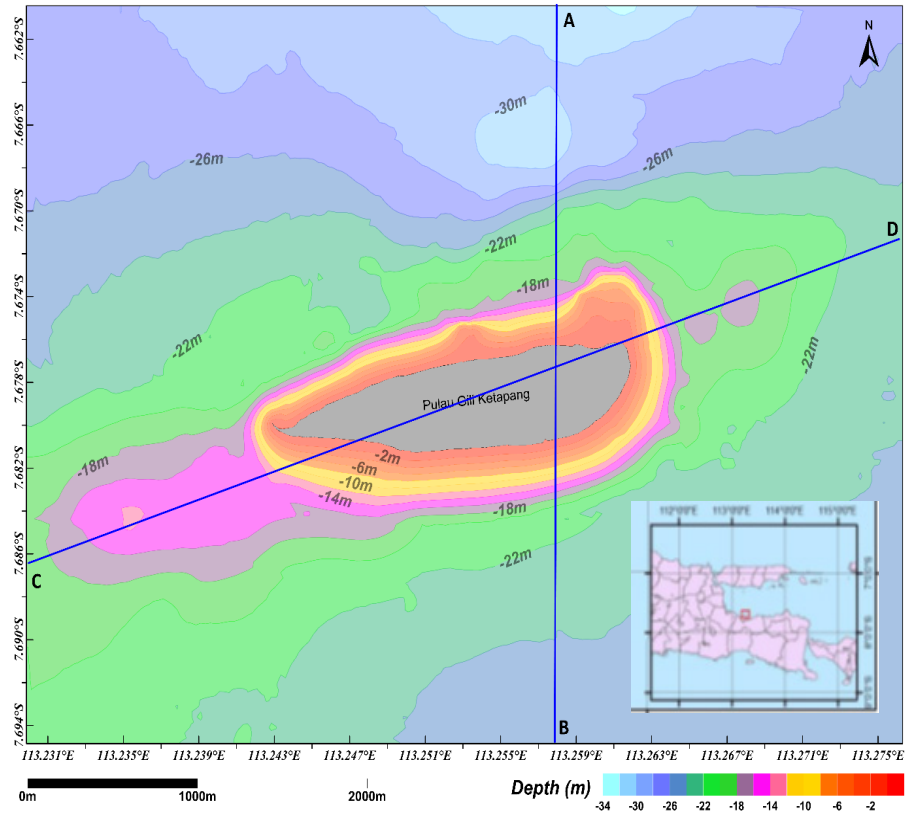

Gambar 5. Batimeti Perairan Gili Ketapang. 

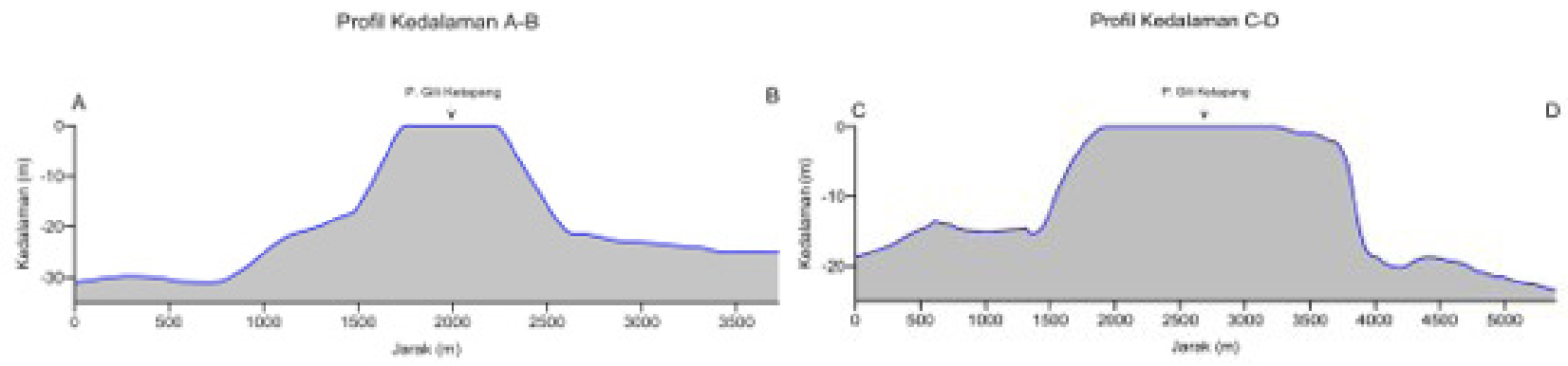

Gambar 6. Profil kedalaman arah Utara-Selatan (A-B) dan Barat Daya-Timur Laut (C-D).

terdalam terdapat disebelah utara Pulau Gili Ketapang dengan jarak sekitar 1700 m (Gambar 5 dan Gambar $6)$.

Secara umum kedalaman perairan di sebelah selatan pulau relatif lebih dangkal bila dibandingkan dengan perairan yang berada di sebelah utara Pulau Gili Ketapang. Di bagian utara pulau kedalamannya mencapai sekitar $32 \mathrm{~m}$ sedangkan di bagian selatan kedalamannya hanya sekitar $25 \mathrm{~m}$. Kemudian terlihat pula bahwa di dekat pantai Pulau Gili Ketapang profil dasar lautnya memiliki kemiringan yang relatif terjal yang ditandai dengan perubahan kedalaman yang secara cepat dari kedalaman 0 hingga sekitar $20 \mathrm{~m}$ pada jarak sekitar $200 \mathrm{~m}$ dari garis pantai dengan persentase kemiringan sekitar 10\% sedangkan semakin ke utara dan ke selatan kemiringan melandai hingga relatif datar (Profil A-B). Sedangkan di sebelah barat pulau relatif lebih dangkal bila dibandingkan dengan perairan yang berada di sebelah utara Pulau Gili Ketapang (Profil C-D). Di bagian barat pulau, dari data yang terukur kedalamannya kurang dari $20 \mathrm{~m}$ sedangkan di bagian timur kedalamannya lebih dari 20 $\mathrm{m}$. sama halnya dengan profil arah utara-selatan, di dekat pantai Pulau Gili Ketapang profil dasar lautnya memiliki kemiringan yang relatif terjal yang ditandai dengan perubahan kedalaman yang secara cepat dari pada jarak sekitar $200 \mathrm{~m}$ dari garis pantai sedangkan semakin ke barat daya dan ke timur laut, kemiringan melandai. Selain itu, terdapat daerah yang relatif datar dengan kedalaman antara $16 \mathrm{~m}-20 \mathrm{~m}$ memanjang ke arah barat daya hingga dari $1,5 \mathrm{~km}$ dengan kemiringan pantai sekitar $1,3 \%$.

\section{Kondisi Arus}

Arus merupakan salah satu faktor yang berperan dalam pengangkutan sedimen di daerah pantai (Hutabarat \& Evans, 1985). Arus laut adalah gerakan massa air dari suatu tempat (posisi) ke tempat yang lain. Arus laut terjadi dimana saja di laut. Pada hakekatnya, energi yang menggerakkan massa air laut tersebut berasal dari matahari. Adanya perbedaan pemanasan matahari terhadap permukaan bumi menimbulkan pula perbedaan energi yang diterima permukaan bumi. Perbedaan ini menimbulkan fenomena arus laut dan angin yang menjadi mekanisme untuk menyeimbangkan energi di seluruh muka bumi. Kedua fenomena ini juga saling berkaitan erat satu dengan yang lain (Azis, 2006)

Arus yang berfungsi sebagai media transpor sedimen akibat adanya deformasi gelombang sehingga menimbulkan arus sejajar pantai (longshore current). Arus sejajar pantai yang membawa sedimen dalam air laut dikenal dengan littoral drift. Bila littoral drift terhalang oleh bangunan massif dapat berpengaruh terhadap proses sedimentasi atau abrasi di pantai.

Arus sejajar pantai ini ditentukan terutama oleh besarnya sudut refraksi gelombang yang dibentuk antara gelombang yang datang dengan garis pantai (Pethick, 1997). Apabila energi arus bekerja pada sedimen maka sedimen akan berpindah tempat mengikuti perpindahan massa air akibat arus. Proses pemindahan sedimen oleh arus ini berawal dari pengadukan sedimen atau resuspensi sedimen yang diakibatkan oleh energi gelombang pecah, selanjutnya sedimen yang tersuspensi kembali ke kolom air akan dipindahkan ke tempat lain bias sejajar atau terbawa kembali ke offshore (Duxbury, 1993) (Gambar 7).

Selain gelombang, pola arus di perairan Gili Ketapang juga sangat dipengaruhi oleh pola arus akibat amplifikasi pasang surut di perairan Selat Madura sehingga terdapat amplitudo pasang surut yang relatif tinggi (mencapai $3 \mathrm{~m}$ ) dibandingkan dengan perairan pesisir Jawa utara pada umumnya (Kusmanto, et al., 2016). Amplifikasi pasang surut menyebabkan kecepatan arus yang relatif tinggi sehingga dapat mempengaruhi kondisi pantai apalagi gumuk pasir yang mudah bergeser.

Poal arus yang terdapat di perairan Gili Ketapang yaitu aliran massa air dari arah timur dan dari arah utara pada musim timur. Massa air yang berasal dari arah timur merupakan massa air dari laut lepas menuju ke Pulau Gili Ketapang dan arus yang mengalir dari arah utara juga menuju ke Pulau Gili Ketapang kemudian bergabung dengan arus yang berasal dari arah timur menuju ke barat - barat daya. Mirip dengan pola arus 


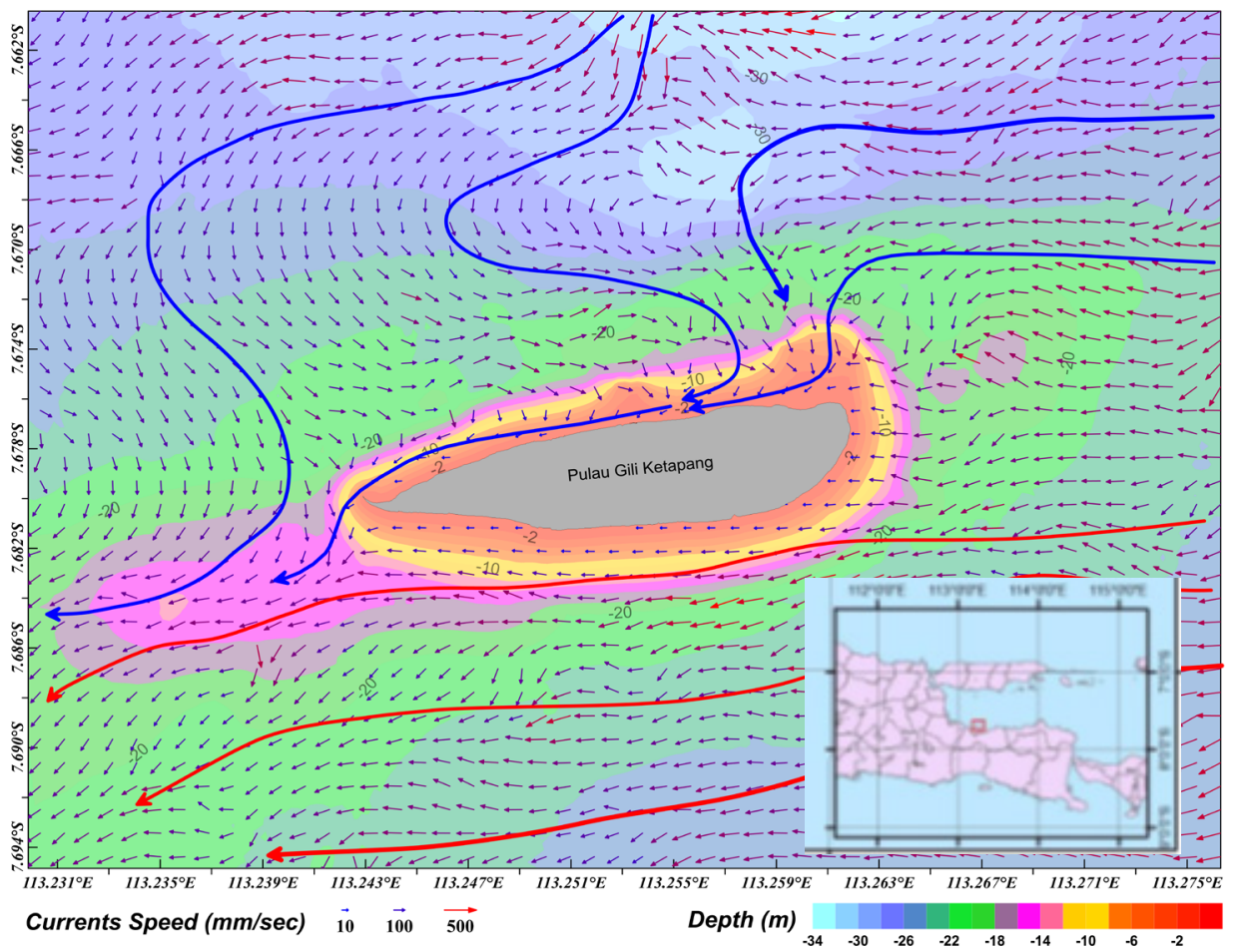

Gambar 7. Arus permukaan di tumpeng susun dengan batimetri di perairan Gili Ketapang, Agustus 2018.

dibagian utara, dibagian selatan terutama dipengaruhi oleh arus yang berasal dari timur. Kisaran kecepatan arus di perairan ini antara $0,539-46,172 \mathrm{~cm} / \mathrm{sec}$.

\section{KESIMPULAN}

Perubahan garis pantai di bagian barat Pulau Gili Ketapang disebabkan oleh berbagai faktor, terutama oleh kecepatan dan arah arus yang sangat berkaitan dengan kontur batimetri perairan Pulau Gili Ketapang. Kecepatan dan arah arus merupakan kontributor utama perubahan bentuk hamparan pasir dengan kecepatan arus di perairan ini antara 0,539 - 46,172 $\mathrm{cm} / \mathrm{sec}$. Pengurangan volumenya kemungkinan besar terbawa arus ke arah barat daya pada kontur batimetri yang lebih dalam atau digunakan oleh penduduk sebagai bahan bangunan oleh penduduk setempat. Hasil analisis data citra Satelit dari 2004 sampai 2018 ditemukan adanya penyusutan luas wilayah untuk pasir putih di bagian barat Pulau Gili Ketapang sebesar 0,288 Ha. Batimetri Perairan Gili Ketapang secara umum memiliki kedalaman terukur antara 0-34 $\mathrm{m}$, Daerah terdalam terdapat disebelah utara Pulau Gili Ketapang dengan jarak sekitar 1700 m. Sebelah Barat dari Pulau Gili Ketapang memiliki dasar laut yang dangkal kurang dari $20 \mathrm{~m}$ sehingga sangat cocok untuk dikembangkan menjadi daerah wisata bahari.

\section{PERSANTUNAN}

Ucapan terimakasih kami sampaikan kepada panitia seleksi Demand Driven Research Grant (DDRG) LIPI tahun 2018 yang telah memberikan dana penelitian. Juga kepada kepala pusat riset kelautan BRSDM KP atas bantuan dan fasilitas yg diberikan. Terakhir, kepada dewan redaksi SEGARA serta pihak reviewer kami ucapkan pula terimakasih atas kerjasamanya hingga tulisan ini dapat diterbitkan. Dino Gunawan Pryambodo, Edi Kusmanto, M. Hasanudin dan Nasir Sudirman adalah sebagai kontributor utama.

\section{DAFTAR PUSTAKA}

Dwinovantyo, A., Manik, H.M., Prartono, T., Susilohadi., \& Ilahude, D. (2017). Estimation of suspended sediment concentration from Acoustic Doppler Current Profiler (ADCP) instrument: A case study of Lembeh Strait, North Sulawesi, Proceedings of the IOP Conference Series: Earth and Environmental Science, 54(1), 012082.

Afrianto, D.A., Sukidin., Suharso, P. (2019). Perubahan kondisi social ekonomi masyarakat pulau giliketapang kecamatan sumberasih kabupaten probolinggosebagai dampak adanya obyek wisata snorkeling. Jurnal Pendidikan Ekonomi, 13(1).

Anzari, R., Hartoni, dan Heron Surbakti, 2017, Pemetaan batimetri menggunakan metode akustik di muara sungai lumpur Kabupaten Ogan Komering Ilir Provinsi Sumatera Selatan, MASPARI JOURNAL, 9(2):77-84.

Azis, M.F. (2006). Gerak Air Dilaut. Oseana, 31(4), 9 -21 . 
Budiyanto, E. (2005). Pemetaan Kontur dan Pemodelan Spasial 3 Dimensi Menggunakan Surfer. Andi Offset. Yogyakarta.

Briju, T., Franklin., \& Teresa. (2013). Impact of Google Earth on Student Learning. International Journal of Humanisties and Social Science, 3(21).

BPS Kab. Probolinggo. (2017). Kabupaten Probolinggo Dalam Angka, ISSN/ISBN: 0215-5788.

Duxbury A.B. \& Duxbury, A.C. (1993), Fundamental of Ocanography. Wm. C. Brown Publisher. Washington. 291 Pages.

Febrianto, T., Hestirianoto, T., \& Agus, S.B. (2015). Pemetaan batimetri di perairan dangkal Pulau Tunda, Serang, Banten menggunakan singlebeam echosounder, Jurnal Teknologi Perikanan dan Kelautan, 6(2).

Hidayati, N., Purnawali, H. S., \& Kusumawati, D.W. (2016). Prediksi perubahan garis pantai Pulau Gili Ketapang Probolinggo dengan menggunakan one-line model. Prosiding Seminar Nasional Perikanan dan Kelautan VI, 4 Mei 2016, Universitas Brawijaya Malang.

Hutabarat, S. \& Evans, S.M. (1985). Pengantar Oseanografi. UI-Press. Jakarta. 159 hal.

Kusmanto, E., Ersan, B.N., \& Arief, D. (1996), Mengenal Direct Reading Acoustic Doppler Current Profiler, Oseana, 21(3), 1-11.

Kusmanto, E., Hasanudin, M. \& Setaiawan, W.B. (2016). Amplifikasi Pasang Surut dan Dampaknya terhadap Perairan Pesisir Probolinggo, Oseanologi dan Limnologi di Indonesia, 1(3), 6980.

Pemerintah Daerah Kabupaten Probolinggo. (2005). Peraturan Daerah Kabupaten Probolinggo No.16 tahun 2005 tentang Tempat tempat Rekreasi Pulau Gili Ketapang.

Pethick. (1997). An Introduction to Coastal Geomorphology. Edward Arnold a Division of Holder and Stougthon, London. 260 Pages.

Siregar, V.P. \& Selamat, M.B. (2009). Interpolator Dalam Pembuatan Peta Batimetri. Departemen IImu dan Teknologi Kelautan, Fakultas Perikanan dan IImu Kelautan, -InstiTut Pertanian Bogor. Jurnal IImu dan Teknologi Kelautan Tropis, 1(1):39-47.
Purwadhi, S.H. \& Sanjoto, T.B. (2008). Pengantar Interpretasi Citra Pengindraan Jauh, LAPAN, Jakarta 